\title{
Penggunaan BA Pada Mikropropagasi Pisang (Musa paradisiaca L.) Kultivar Kusto
}

\author{
Reni Apriani $^{1)}$, Tri Mulyaningsih ${ }^{1)}$, Rina Kurnianingsih ${ }^{1)}$, dan Fitrahtunnisa ${ }^{2}$ \\ ${ }^{1}$ Program Studi Biologi, Fakultas MIPA, Universitas Mataram \\ Jl. Majapahit No. 62, Mataram \\ ${ }^{2}$ Balai Pengkajian Teknologi Pertanian Nusa Tenggara Barat \\ Jl. Raya Peninjauan, Narmada
}

\begin{abstract}
ABSTRAK
Penelitian ini bertujuan untuk mengetahui pengaruh konsentrasi Benziladenin (BA) terhadap mikropropagasi pisang (Musa paradisiaca L.) kultivar Kusto. Penelitian dirancang menggunakan RAL dengan 6 taraf perlakuan konsentrasi Benziladenin $(2,3,4,5,6$ dan 7 $\mathrm{mg} / \mathrm{l}$ ), setiap perlakuan terdiri dari 5 ulangan. Hasil penelitian menunjukkan bahwa peningkatan konsentrasi BA tidak berpengaruh nyata terhadap waktu muncul tunas, jumlah tunas dan panjang tunas. Waktu muncul tunas tercepat (36,67 hst) didapat pada perlakuan 6 $\mathrm{mg} / \mathrm{l} \mathrm{BA}$, panjang tunas tertinggi $(2,38 \mathrm{~cm})$ pada perlakuan $4 \mathrm{mg} / \mathrm{l} \mathrm{BA}$ dan jumlah tunas terbanyak (1,6 tunas) pada perlakuan $7 \mathrm{mg} / \mathrm{l} \mathrm{BA}$.

Kata kunci: Musa paradisiaca, pisang 'Kusto', mikropropagasi, kultur jaringan.
\end{abstract}

\section{ABSTRACT}

The aim of this research was to study the effect of Benzyladenine consentrations on micropropagation of banana (Musa Paradisiaca L.) cultivar Kusto. The experiment used completely randomized design with 6 level treatments of Benzyladenine consentration $(2,3$, 4, 5, 6 and $7 \mathrm{mg} / \mathrm{l}$ ), each treatment consisted of 5 replications. The result of the experiment showed that the treatments did not significantly effect the shoots formation time, the number of shoots and the length of shoots. The fastest shoots formation time (36,67 hst) was observed in treatment $6 \mathrm{mg} / \mathrm{l} \mathrm{BA}$, the highest length of shoots $(2,38 \mathrm{~cm})$ in treatment $4 \mathrm{mg} / \mathrm{l} \mathrm{BA}$ and the highest number of shoots (1,6 shoots) in treatment $7 \mathrm{mg} / \mathrm{l} \mathrm{BA}$.

Key words: Musa paradisiaca, banana 'Kusto', micropropagation, tissue culture. 


\section{PENDAHULUAN}

buah $\begin{array}{lr}\text { yang } & \text { menjadi } \\ \text { unggulan daerah Nusa } & \text { Tenggara }\end{array}$

Barat dan salah satu kultivar yang memiliki peluang pasar tinggi atau banyak diminati konsumen ialah pisang 'Susu' (Erawati et al., 2006). Pisang 'Susu' yang telah dikenal luas oleh masyarakat memiliki banyak ragam, salah satunya ialah pisang 'Kusto'. Pisang 'Kusto' termasuk kedalam jenis pisang 'Susu' yang memiliki ciri khas yaitu terdapat bintik-bintik kehitaman yang tersebar pada seluruh permukaan kulit buahnya. Di Lombok, pisang 'Kusto' merupakan salah satu jenis pisang yang telah mampu beradaptasi baik dengan kondisi iklim setempat dan dari dulu telah dibudidayakan oleh para petani lokal .

Pisang 'Kusto' termasuk kultivar pisang meja yang bernilai ekonomis tinggi dan cukup digemari oleh masyarakat karena rasanya yang manis dan tekstur daging buahnya lembut dan lunak. Namun keberadaan pisang ini di pasaran, tidak secara kontinyu ada. Dengan kata lain jumlah permintaan pasar tidak diikuti dengan peningkatan jumlah produksi pisang 'Kusto'. Hal ini disebabkan karena cara budidanya yang masih secara konvensional sehingga jumlah bibit yang dihasilkan terbatas. Perbanyakan pisang 'Kusto' melalui teknik kultur jaringan (in vitro) merupakan alternatif terbaik untuk menghadapi permasalahan penyediaan bibit dalam jumlah besar tersebut.

Kultur jaringan merupakan cara pembiakan vegetatif yang cepat dan secara genetik sifat-sifat tanaman anak yang dihasilkan akan sama atau identik dengan induknya (Rainiyati et al., 2007). Selain itu, bibit pisang hasil kultur jaringan pertumbuhannya lebih pesat, seragam, dapat disediakan dalam jumlah banyak dengan waktu yang singkat, dan bebas patogen berbahaya (Avivi dan Ikrarwati, 2004). Dalam perbanyakan in vitro, penggunaan zat pengatur tumbuh sangat penting untuk mengontrol proses organogenesis dan morfogenesis (Lestari, 2011). Benziladenin (BA) merupakan salah satu zat pengatur tumbuh golongan sitokinin yang umum digunakan dalam perbanyakan pisang melalui teknik kultur jaringan.

Dalam kultur jaringan sering dijumpai adanya respon eksplan yang berbeda terhadap formulasi media (Lestari et al., 2013). Respon tersebut dipengaruhi oleh genotipe, fase fisiologis eksplan dan ditentukan juga oleh jenis, struktur kimia serta konsentrasi zat pengatur tumbuh yang ditambahkan ke dalam media kultur (Satyavathi et al., 2004). Dengan demikian maka perlu dikaji tentang penggunaan BA pada mikropropagasi pisang 'Kusto' karena pisang kultivar ini memiliki potensi besar untuk dikembangkan dalam skala besar di kawasan Lombok.

Penelitian ini bertujuan untuk mengetahui pengaruh beberapa taraf konsentrasi BA terhadap mikropropagasi kultivar pisang Kusto. Sehingga tercapai tujuan untuk mendapat teknologi yang mampu memenuhi kebutuhan bibit pisang 'Kusto' dalam waktu singkat dengan jumlah banyak. Manfaat yang diharapkan dari hasil penelitian ini yaitu menjadi suatu bahan informasi yang dapat digunakan sebagai rujukan penelitian sejenis yang selanjutnya.

\section{BAHAN DAN METODE}

Penelitian dilakukan di Balai Pengkajian Teknologi Pertanian NTB dari bulan Mei sampai dengan November 2015.

Bahan tanam (eksplan) yang digunakan adalah anakan pisang 'Kusto' yang sehat dengan tinggi $15-20 \mathrm{~cm}$. Sterilisasi eksplan dilakukan dengan 
membersihkan anakan dari tanah kemudian dikupas dan ukurannya diperkecil, selanjutnya dicuci dengan menggunakan detergent cair dan dibilas dengan air mengalir. Eksplan yang telah dicuci bersih kembali dikupas dan dipotong beberapa kali. Tiap pengupasan, eksplan disemprot dengan alkohol $70 \%$. Setelah mencapai ukuran yang diinginkan, eksplan kemudian direndam dalam aquadest steril dan selanjutnya disterilisasi dalam laminar air flow berturutturut menggunakan Bayclin 20\% selama 10 menit, Bayclin 10\% selama 5 menit, Bakterisida (Agrept) selama 10 menit dan terakhir alkohol $70 \%$ selama 1 menit kemudian eksplan dipaparkan dengan api bunsen untuk membunuh mikroorganisme yang ada dipermukaan eksplan. Sebelum penanaman pada media kultur, ukuran eksplan diperkecil lagi hingga berdiameter sekitar $3 \mathrm{~cm}$ dan tinggi $1,5 \mathrm{~cm}$.

Eksplan yang telah disterilisasi ditanam pada media prekondisi dengan formulasi $1 \frac{1}{2} \mathrm{MS}+2 \mathrm{gr} / \mathrm{l}$ arang aktif. Setelah 4 minggu ditanam dalam media prekondisi, eksplan dipecah menjadi 6 bagian yang kemudian ditanam pada media perlakuan dengan formulasi media MS + BA (2, 3, 4, $5,6$, dan $7 \mathrm{mg} / \mathrm{l})$. Botol yang sudah ditanami eksplan selanjutnya diletakkan di dalam ruang kultur dengan suhu $25 \pm 2{ }^{\circ} \mathrm{C}$ dan penyinaran menggunakan lampu TL 18 Watt. Pengamatan dilakukan selam 3 bulan dengan subkultur eksplan dilakukan setiap 4 minggu sekali.

Rancangan percobaan adalah acak lengkap, terdiri atas 6 perlakuan dan ulangan sebanyak 5, sehingga terdapat 30 unit percobaan. Parameter yang diamati meliputi perubahan eksplan (pembengkakan eksplan, browning, terbentuknya kalus dan embrioid), waktu kemunculan tunas, jumlah tunas dan panjang tunas. Data hasil pengamatan dianalisis secara statistik dengan menggunakan ANOVA sedangkan untuk parameter perubahan eksplan dilakukan analisis secara deskriptif.

\section{HASIL DAN PEMBAHASAN \\ Perubahan eksplan}

Eksplan yang dikultur secara in vitro menunjukkan perubahan awal 7 hari setelah tanam pada media perlakuan (Gambar 1a), yaitu berupa perubahan warna menjadi kecoklatan yang menandakan bahwa eksplan mengalami browning yang disebabkan oleh oksidasi senyawa fenolik akibat jaringan eksplan yang dilukai (Gunawan, 1988). Hal ini disebabkan oleh aktivitas enzim oksidase yang mengandung tembaga seperti polifenol oksidase dan tirosinase yang dilepaskan atau disintesis dan tersedia pada kondisi oksidatif ketika jaringan dilukai (Hutami, 2008). Selain itu, Onuoha et al. ( 2011) juga menjelaskan bahwa pada jaringan pisang mengandung komponen enzim-enzim fenolik terutama enzim polifenol oksedase yang secara alami merupakan fito-auksin yang penting pada pisang. Pencoklatan ini pertama terlihat dibagian permukaan bawah eksplan yang kemudian terus meluas sejalan dengan semakin bertambahnya waktu kultur hingga menyebar hampir ke seluruh permukaan eksplan (Gambar 1b). Pada kultur pisang 'Kusto' ini, semua eksplan browning dan diduga menjadi faktor yang menghambat pertumbuhan eksplan sehingga proses inisiasi tunas dari eksplan juga terhambat.

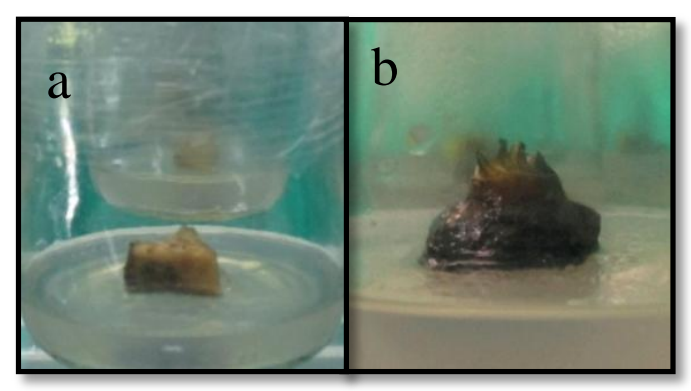


Gambar 1. (a) Eksplan yang mulai browning dan (b) eksplan yang seluruh permukaannya browning.

Pembengkakan eksplan teramati pada 10 hari setelah eksplan ditanam pada media perlakuan dan pada beberapa eksplan, pembengkakan ini diikuti dengan munculnya kalus yang berwarna putih dengan struktur seperti butiran-butiran halus (Gambar 2a). Sedangkan munculnya embrioid (Gambar 2b) teramati pada perlakuan P4 (5 mg/l BA). Proses munculnya kalus diawali dengan penebalan eksplan pada bagian potongan dan di daerah yang mengalami pelukaan. Penebalan tersebut merupakan interaksi antara eksplan dengan media tumbuh, zat pengatur tumbuh dan lingkungan tumbuh sehingga eksplan bertambah besar (Yelnititis, 2012). Pada penelitian ini, diduga munculnya kalus pada eksplan karena aktivitas auksin endogen yang terdapat secara alami dalam eksplan yang berinteraksi dengan BA yang diberikan ke dalam media kultur. Seperti yang dijelaskan oleh Yadav dan Tyagi (2006) bahwa pembentukan dan proliferasi kalus dalam kultur in vitro dipicu oleh adanya hormon auksin dan sitokinin dalam media yang mempercepat proses pembelahan dan pemanjangan sel. Sedangkan munculnya embrioid pada eksplan yang berkalus menandakan bahwa kalus yang terbentuk dari eksplan merupakan kalus embrionik yang dapat berkembang membentuk plantlet melalui proses embriogenesis somatik.

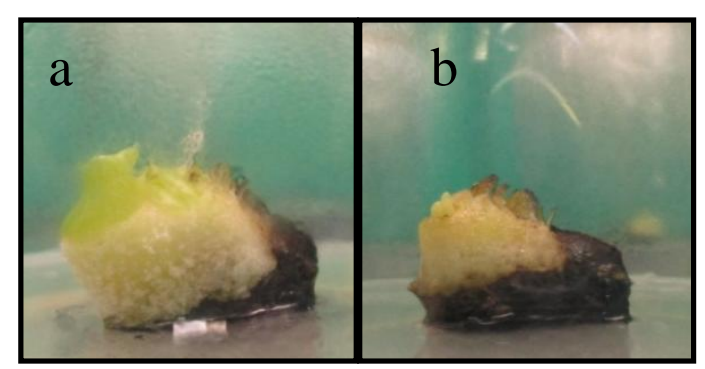

Gambar 2. (a) Munculnya kalus pada eksplan dan (b) embrioid yang muncul pada eksplan di perlakuaan P4.

\section{Waktu kemunculan tunas}

Hasil analisis sidik ragam menunjukkan semua perlakuan taraf konsentrasi BA tidak memberikan pengaruh nyata terhadap waktu kemunculan tunas pisang 'Kusto'. Perlakuan taraf konsentrasi BA terhadap waktu kemunculan tunas dapat dilihat pada histogram 1 dibawah ini:

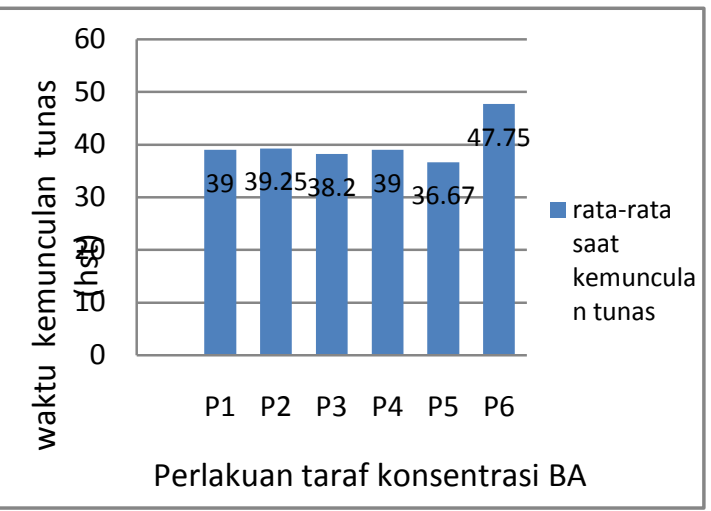

Histogram 1. Perlakuan taraf konsentrasi BA terhadap waktu kemunculan tunas.

Histogram 1. menunjukkan bahwa rata-rata waktu kemunculan tunas tercepat terjadi pada perlakuan P5 $(6 \mathrm{mg} / \mathrm{l})$ yaitu 36,67 hari setelah eksplan ditanam pada media perlakuan dan rata-rata waktu kemunculan tunas terlama didapat pada perlakuan P6 (7 mg/l BA) yaitu 47,75 hst. Berdasarkan histogram 1 juga dapat disimpulkan bahwa penambahan $2 \mathrm{mg} / \mathrm{l} \mathrm{BA}$ telah mampu menginduksi pembentukan tunas pada pisang 'Kusto'. Hasil ini sesuai dengan hasil penelitian yang dilaporkan oleh Lee (2005), bahwa penambahan $2 \mathrm{mg} / \mathrm{l} \mathrm{BA}$ 
mampu menginduksi terbentuknya tunas pada pisang 'Cavendish'. Tidak jauh berbeda dengan hasil penelitian Rios et al. (2013) pada pisang 'Cambur Manzano' dengan penambahan $2,5 \mathrm{mg} / \mathrm{l}$ BA sudah mencukupi untuk induksi dan multiplikasi tunas.

\section{Jumlah tunas}

Berdasarkan hasil analisis sidik ragam, perlakuan taraf konsentrasi BA tidak berpengaruh nyata terhadap jumlah tunas yang terbentuk dari eksplan pisang 'Kusto' pada $12 \mathrm{mst}$ (minggu setelah tanam). Adapun Perlakuan taraf konsentrasi BA terhadap jumlah tunas dapat dilihat pada histogram 2 dibawah ini:

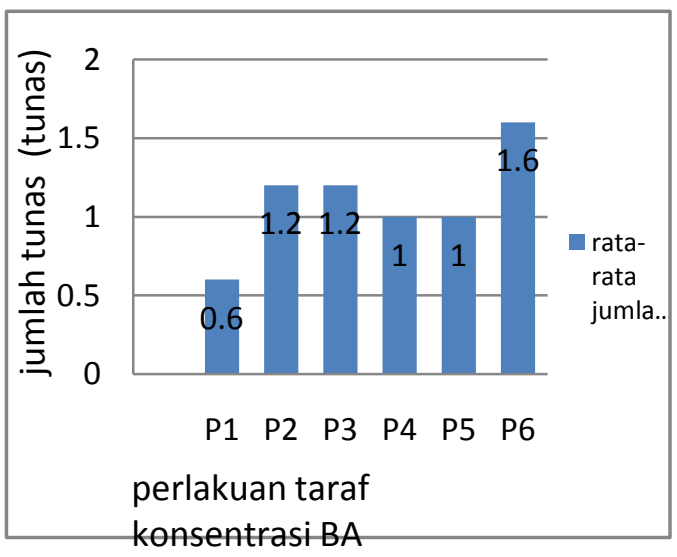

Histogram 2. Perlakuan taraf konsentrasi BA terhadap jumlah tunas.

Dari histogram 2. Terlihat bahwa rata-rata jumlah tunas yang muncul dari eksplan pisang 'Kusto' terbanyak didapatkan pada perlakuan P6 (7 mg/l BA) yaitu sebanyak 1,6 tunas. Hasil yang sama juga dilaporkan dari hasil penelitian Hussein (2012) pada pisang (Musa spp.) bahwa proliferasi tunas tertinggi diperoleh pada media dengan penambahan $7 \mathrm{mg} / \mathrm{l}$ BA. Selain itu, Bhosale et al. (2011) juga melaporkan bahwa $7 \mathrm{mg} / \mathrm{l}$ BAP memberikan rata-rata jumlah tunas terbanyak pada pisang 'Basrai' dan 'Ardhapuri'.
Berdasarkan Histogram 2 juga terlihat bahwa rata-tara jumlah tunas yang terbentuk pada pisang 'Kusto' sedikit, yang diduga karena pisang 'Kusto' memiliki tingkat proliferasi tunas yang rendah. Hasil serupa juga dilaporkan oleh Rios (2013) pada pisang 'Cambur Manzano' yang hanya mampu menghasilkan rata-rata tunas sebanyak 1,5 tunas, serta tidak terdapat signifikansi tiap perlakuan terhadap jumlah tunas yang terbentuk.

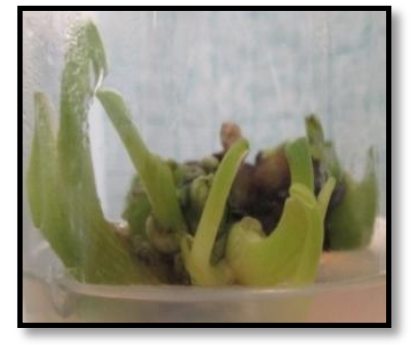

Gambar 3. Eksplan dengan jumlah tunas terbanyak (P6).

\section{Panjang tunas}

Hasil analisis sidik ragam menunjukkan perlakuan taraf konsentrasi BA tidak berpengaruh nyata terhadap panjang tunas yang terbentuk dari eksplan pisang 'Kusto' pada 12 mst (minggu setelah tanam). Adapun perlakuan taraf konsentrasi BA terhadap panjang tunas dapat dilihat pada histogram 3 dibawah ini:

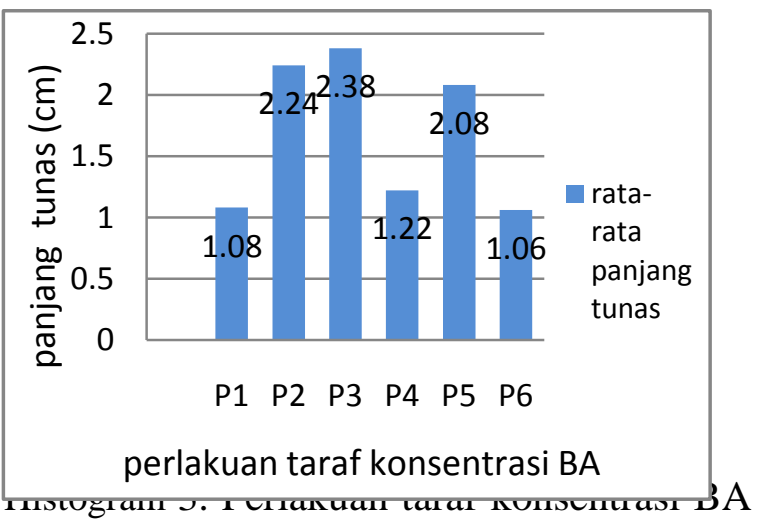
terhadap panjang tunas.

Histogram 3. Menunjukkan bahwa rata-rata panjang tunas tertinggi didapatkan 
pada perlakuan P3 (4 mg/l BA) yaitu 2,38 $\mathrm{cm}$. Hasil yang sama juga dilaporkan oleh Shankar et al. (2014), pada pisang 'Grand Nain' pemberian BAP sebesar $4 \mathrm{mg} / \mathrm{l}$ menghasilkan panjang tunas tertinggi. Sedangkan pada penelitian Andriana (2005), perlakuan $4 \mathrm{mg} / \mathrm{l}$ BAP memberikan hasil rata-rata panjang tunas tertinggi pada subkultur keempat pisang FHIA-17.

Berdasarkan histogram 3, terlihat juga bahwa pada rentang perlakuan P1 (2 mg/l BA) - P3 (4 mg/l BA), panjang tunas berbanding lurus dengan taraf konsentrasi BA, yaitu semakin tinggi konsentrasi BA maka rata-rata panjang tunas semakin tinggi. Namun pada konsentrasi BA yang lebih tinggi, terjadi penurunan tinggi tunas. Hasil ini sesuai dengan yang dijelaskan oleh Bhojwani dan Rhazdan, 1983 (dalam Rainiyati et al., 2007) bahwa sitokinin (BA) sangat efektif dalam merangsang pembentukan tunas. Semakin tinggi konsentrasi sitokinin, jumlah tunas yang terbentuk semakin bertambah tetapi pembentukan masing-masing tunas seperti penambahan tingginya akan terhambat.

\section{SIMPULAN}

1. Pemberian perlakuan beberapa taraf konsentrasi BA tidak berpengaruh nyata terhadap waktu kemunculan tunas, jumlah tunas dan tinggi tunas.

2. Rata-rata waktu kemunculan tunas tercepat (36,67 hst) dicapai pada perlakuan $6 \mathrm{mg} / \mathrm{l}$ BA. Rata-rata jumlah tunas terbanyak (1,6 tunas) dicapai pada perlakuan $7 \mathrm{mg} / \mathrm{l} \mathrm{BA}$. Sedangkan untuk rata-rata panjang tunas tertinggi $(2,38$ $\mathrm{cm}$ ) dicapai pada perlakuan $4 \mathrm{mg} / \mathrm{l}$ BA.

\section{DAFTAR PUSTAKA}

Andriana, D. 2005. Pengaruh konsentrasi BAP terhadap multiplikasi tunas dan giberelin terhadap kualitas tunas pisang fhia-17 in vitro. (Skripsi). Bogor: Institut Pertanian Bogor.

Avivi, S. dan Ikrarwati. 2004. Mikropropagasi pisang Abaca (Musa textillis Nee) melalui teknik kultur jaringan. Ilmu pertanian. 11(2): 27 34.

Bhosale, U.P., S.V. Dubhashi, N.S. Mali dan H. P. Rathod. 2011. In vitro shoot multiplication in different species of banana. Asian Journal of Plant Science and Research. 1(3): 23-27.

Erawati, T.R., A. Hipi dan A. Susanto. 2006. Pengaruh asal bibit terhadap pertumbuhan beberapa jenis pisang di lahan kering NTB. http://ntb.litbang.pertanian.go.id.

Diakses 30 Maret 2015.

Gunawan, L.W. 1988. Teknik kultur jaringan tumbuhan. Pusat Antar Universitas Bioteknologi. Institut Pertanian Bogor. Bogor. p.: 303.

Hussein, N. 2012. Effects of nutrient media constituents on the growth and development of banana (Musa spp.) shoot tips cultured in vitro. African Journal of Biotechnology. 11(37): 9001-9006.

Hutami, S. 2008. Ulasan masalah pencoklatan pada kultur jaringan. Jurnal AgroBiogen. 4(2): 83-88.

Lee, S.W. 2005. Thidiazuron in the improvement of banana micropropagation. Taiwan Banana Research Institute. Acta Hort. 69(2): 67-74.

Lestari, E.G. 2011. Peranan zat pengatur tumbuh dalam perbanyakan tanaman 
melalui kultur jaringan. Jurnal AgroBiogen. 7(1): 63-68.

Lestari, E.G., M.R. Suhartanto, A. Kurniawati dan S. Rahayu. 2013. Inisiasi tunas ganda tanaman manggis Malinau melalui kultur in vitro untuk perbanyakan klonal. $J$. Agron. Indonesia. 41(1): 40-46.

Onuoha, I.C., C.J. Eze dan C.I.N. Unamba. 2011. In vitro prevention in plaintain culture. Online Journal of Biological Sciences. 11(1): 13-17.

Rainiyati, D. Martino, Gusniwarti dan Jasminarni.2007. Perkembangan pisang Raja Nangka (Musa sp.) secara kultur jaringan dari eksplan anakan dan meristem bunga. Jurnal Agronomi. 11(1). 35-40.

Rios, G., N. Anez, M. Ramizel, B. Bracho, D. Araujo, H. Suarez and J. Nava. 2013. In vitro culture of bud, treated of benzyadenine, coming from whole and sectioned corm of plantain 'Cambur manzano'. Bioagro. 25(2): 137-142.
Satyavathi, V.V., P.P. Jauhar, E.M. Elias and M.B. Rao. 2004. Genomics, molecular genetic and biotechnology effects of growth regulators on in vitro regeneration. Crop Sci. 44: 1839-1846.

Shankar, C.S., P. Balaji dan D.S. Sekar. 2014. Mass propagation of banana (Musa sp.) cv. Graind Naine through direct organogenesis by Benzyl Adenine Purin and Kinetin. Journal of Academia and Industrial Research. 3(2): 92-97.

Yadav, P.R. Dan R. Tyagi. 2006. Biotechnology of plant tissue. Discovery Publishing House. New Delhi. p.: 246.

Yelnititis. 2012. Pembentukan kalus remah dari eksplan daun Ramin (Gonystylus bancanus (Mirq) Kurz.). Jurnal Pemuliaan Tanaman Hutan. 6(3): 181-194. 